\title{
Exploration on the Cultivation of Innovative Ability of Military University Students
}

\author{
Zhang Xiaoming \\ Department of Mechanical Engineering \\ Academy of Armored Force Engineering \\ Beijing 100072, China \\ true7742@163.com
}

\begin{abstract}
Focusing on the problem that cadets are unwilling, afraid and do not know how to innovate due to the enclosed environment, their blinkered way of thinking and lack of innovation skills, based on "elite education with tutorial system" and "management mechanism of self-organization", the paper creates a set of training methods of innovation ability for military academies, which can effectively improve the innovation ability of military cadets and promote their learning ability and overall quality.
\end{abstract}

Keywords-cadets; innovation ability; tutorial system; self-organization

\section{INTRODUCTION}

With the accelerating of the new military revolution in the world, competition in the military field is more intense, which requires the cultivation of talents in the military field to correspond with the time and fulfill the historical missions. Central Military Commission pointed out in the Outline of Military Talents Development Plan Before 2020 and Outline of educational reform and development plan for military academies before 2020 that talent development is the key in the construction of army [1]. It is the main part of the implementation of "the Reinvigorating China through Human Resource" and the important guarantee for modernizing national defense and armed forces that require to intensively press ahead with the military talent strategy and cultivating a large number of new high-quality military personnel. A teaching pattern that is oriented to train cadets' ability to learn, to practice and to innovate and is adapted to the requirement of cultivating new-type military talents need to be established, as shown in Figure 1. The two outlines have made clear request about training innovative talents in the new era, making the cultivation of cadets' innovation ability be promoted to the strategic level.

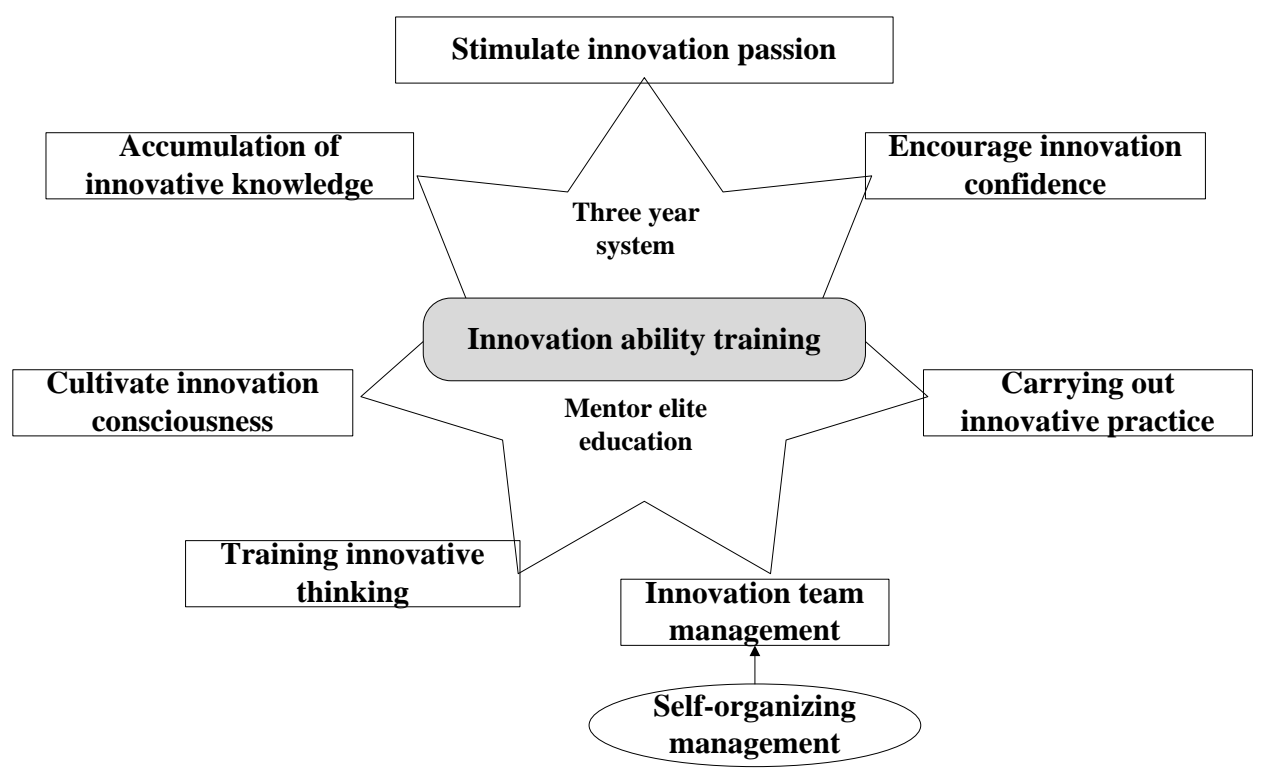

Fig. 1. Ways to cultivate innovative ability of undergraduates 
As required in the outlines, focusing how to stimulate the enthusiasm of undergraduates to innovate; how to improve cadets' innovative ability; how to effectively train cadets' innovative mind; how to instruct cadets to carry out innovative practice efficiently; how to teach cadets to manage their innovation team, etc. the paper has explored an appropriate way adapted to cultivate cadets' innovative ability, which include "1 line, 7 procedures and 1 mechanism", that is to say, a line of 3-year elite education with tutorial system, 7 procedures including accumulating innovation knowledge, inspiring innovation passion, cultivating innovation awareness, training innovative way of thinking, carrying out innovation practice, encouragement and team management and 1 management mechanism of self-organizing office-style laboratory. The method has cultivated many grass-roots officers with certain innovation ability and a group of military top-notch innovative talents with high-quality [2].

\section{ORGANIZING INNOVATION COMPETITION, ENHANCING}

\section{INNOVATION RESULT AND CORRECTLY GUIDING CADETS'}

\section{PASSION IN INNOVATION.}

When carrying out competitions, academy adopts the pattern of "introducing and promoting" to increase interaction by combining college festivals for science and technology with some innovative activities, such as "National Contest of Application in Internet of Things", "China Robot Competition and Robocup open", "Freescale Cup National Smart Car of university students", "the Challenge Cup National College Students Extracurricular Science and technology works competition". The academy also organizes perennially "Competition of Innovative Application in Sensor and Robot Creative Design", which has different themes every year, such as "Walking Robot Race", "Robot Weight-bearing Obstacle Race" and "Innovation competition in Internet of Things", etc. Students will take an interest in seeking knowledge and innovation after they understand some relevant technologies which are not taught in daily education by joining special technical seminar before the competition [3]. They will become more enthusiastic about innovation once they independently finish their first piece of work, especially which has won a prize. The innovation studios have built long-term relationships with the students S\&T innovation organization of local universities, such as Tsinghua, BEIHANG and BIT (Beijing Institute of Technology) and have been organizing fellowship activities, thus the academy can exhibit the innovations from other universities during the competitions.

Moreover, the instructions from tutors can help students summarize their experience of innovation products, even apply for a patent and write a research paper, thus increasing their sense of accomplishment and improving their motivations. Most students used to put their innovation aside after winning an award and stop further research, which, on one hand, did not make use of their original incentive, on the other hand, had a negative effect on their future in the army. If they do research on weaponry after graduation, their innovations may be shallow, hence those innovations will not be considered as real innovations. The study report of American National Academy pointed out that innovation is the idea that can be realized now or in the near future, which means that those ideas that cannot be realized are not real innovations. Therefore, when cultivating undergraduates' innovation ability, the teachers should guide students to lucubrate and summarize, even help them apply for a patent and write a paper. When witnessing their names printed on learned periodicals or letters patents, they will feel much happier than when they just win a prize. Only in this way can their inner driving force for innovation be stimulated.

Finally, the academy can make the achievements of cadets wildly known through various Medias, including newspapers, internet, radios or TV stations to enhance their sense of pride and, at the same time, to advertise and promote the distinguished innovations, thus helping realize these ideas. Appropriate advertisement can also increase students' willingness to participate and arouse their curiosity and interest in invention. Students' confidence and passion in innovation soar through these methods.

\section{Cultivating Students' AWARENESS AND INNOVATIVE}

\section{THINKING BY THE 3-YEAR ELITE EDUCATION WITH TUTORIAL}

\section{SYSTEM}

The traditional indoctrination education model should be abandoned. The academy has adopted 3-year elite education with tutorial system from the sophomore year to the senior year, that is, a tutor trains a group of sophomores in the same innovation studio to improve their awareness and innovation thinking and instructs their practice. Freshmen learn how to increase their basic knowledge about innovation either as judges or audience of some innovation competition or through introduction seminar.

\section{A. Raising the students' consciousness in innovation}

Realizing to innovate is the precondition of innovative thinking. Students' passion of innovation will be released and their consciousness to innovate will form by "imitative education" and "interactive education" in 3 aspects: consciousness of subjectivity, consciousness of asking questions and consciousness of going beyond, as shown in Figure 2.

"To impart knowledge, to introducing methods and to solving puzzles" is the education philosophy of Chinese which has been handed down from thousands of years ago. Teachers are regarded as the owner and sender while students the passive receiver. This way of transmitting culture is passive, making students form a dependent way of thinking in studying which cannot be broken easily.

To cultivate students' consciousness of subjectivity is to arouse and highlight students' individual value, which means that students strongly realize that they are their own master and they should learn actively. Students should learn to build self-esteem with the confidence that they are born with a gift, thus learning and participating actively. They should live and learn with a sense of social responsibility that "heaven is about to confer office on somebody".

It is important to cultivate students' consciousness of finding problem. Doubt matters in study. Li Zhengdao once said that "He who cannot ask questions cannot do top job". 
Doubt is the inducement to make brain work and it is also where the innovative thinking begins. Teachers need to encourage students to be curious and not to be content with the knowledge and conclusion they have already known, to encourage them to explore, to doubt and to create. And to train students' awareness of going beyond is to encourage them to be unique, which requires the courage to challenge books, superiors, teachers and predecessor as well as authority. Dare to surpass means the beginning to innovate.

\begin{tabular}{|c|c|}
\hline Subject consciousness & \multicolumn{1}{|c|}{} \\
\hline Problem consciousness & $\rightarrow$ Innovation consciousness \\
\hline Transcendental consciousness \\
\hline
\end{tabular}

Fig. 2. Three aspects of cultivating innovative consciousness

\section{B. Helping students form divergent thinking}

In class, teachers can make the most of every possible opportunity to train the divergent thinking of students and guide them to think from different perspectives, thus they can learn how to solve a problem effectively with various ways. What a teacher needs to pay attention is as follows: divergent thinking is different from thinking wildly, playing intellectual games or exaggerating the role of divergent thinking. The instructor must guide students to adopt new ways to effectively deal with problems without hurting their enthusiasm about thinking actively. Divergent thinking advocates broaden mind which remains down-to-earth and to the point, for the way of thinking should keep pace with the development of society. After years of training, students' innovative thinking has been in line with the time. They know high technologies, such as "smart courier bag", "car alarm system in which the passengers can be linked", "responsive electronic equipment label" and "video monitoring and alarming network on the brain waves of epilepsy patients" instead of "blackboard erasers" or "dustbins". Once in a field work, some cadets found it was difficult to build a sand table model and the interactivity and verisimilitude of those models were poor. Thus they tried many other ways, such as projecting screen and liquid-crystal display to substitute the existing sand table and finally developed a "live" sand table with light-modulating film, which solve a problem in reality and won National Grand Prize.

\section{ORGANIZING PROFESSIONAL TRAINING IN "WHAT YOU SHOULD KNOW AND DO" AND ACADEMIC SALON ON CUTTING-EDGE TECHNOLOGIES TO HELP STUDENTS ACCUMULATE INNOVATIVE KNOWLEDGE AND INSTRUCT THEM TO CARRY OUT INNOVATIVE PRACTICE EFFICIENTLY}

Cadets who join in the innovative studio are trained in batches by teasing out the innovative expertise in "what you should know and do" and writing instruction book on innovation practices. Students learn specific curriculums for different research fields, such as embedded system hardware design, software design, and mechatronics system optimization. Academic salons of cutting-edge technology are organized and students are trained purposefully about how to use tools for innovations, thus amassing knowledge in innovation. Many laboratories are built and available to students. In laboratory, the tutor's research experiences are shared selflessly with students, for example, what companies can students apply for free components from? How do they buy various components on the Internet? Where can they process mechanical parts of different kinds? How can they quickly process circuit board? How to retrieve patent and papers and know developments in relevant technologies and even acquire inspirations?

These experiences help improve students' efficiency and completion rate.

\section{STRENGTHENING TUTORS INNOVATIVE THOUGHT AND PERSONAL QUALITY, ENHANCING STUDENTS' CONFIDENCE IN INNOVATION AND CULTIVATING STUDENTS' RIGOROUS} ATTITUDE.

The tutors in innovation studios are open in structure, from which students can select freely. Teachers can apply without restrictions and rigid requirements, as long as they are passionate and responsible for students. If the tutor is not responsible or does not know much about innovation, he will not be chosen. $80 \%$ of the tutors are doctor, they take part in brainstorm activities regularly and are asked to be members of organizing committee in national innovation competitions to keep up with the trend and enhance their own innovative mind. The role of the tutor runs through the 7 procedures, of which the core is tutors' own advanced innovative ideas. At the very beginning, most students' innovation thinking is from guidance of their tutor. They start independent innovation only after some successful attempts. In addition, in the communication about divergent thinking, the tutor should bring students' wildly thinking back to the theme to solve real problems.

The tutors' passion and responsibility are not only to support students, but also to encourage students to be brave when they are faced with difficulties, failures or sneers. It is necessary to create convenience for them and make them feel confident. The road to innovation is filled with setbacks, for innovation itself is a complicated program. Some students shrink when difficulties appear. For instance, one team that were going to develop an intellectual on-board alarm system felt discouraged then intended to quit the program after they suddenly found their design had already been mandatory installment in foreign countries. But after analyzing the pros and cons of the foreign products with their tutor, they creatively put forward to connect passengers with internet of vehicle through an on-board terminal, thus developed a user-friendly and powerful alarm system using the RFID technology. This innovation has won a gold prize and has applied for a patent successfully.

Besides, good behaviors and strict requirements of innovations will have a positive influence on their students' attitude unconsciously. 


\section{CREATING MANAGEMENT MECHANISM OF}

\section{SELF-ORGANIZATION TO STRENGTHEN THE TEAM}

\section{MANAGEMENT SKILLS AND TEAM SPIRITS}

Management mechanism of self-organization is derived from evolutionary organization theory of a German theoretical physicist, Haken, who said if a system is organized by external instructions, it can be call "heter-organization", if an organization is automatically and orderly formed free from external instruction, it can be called self-organization. Students are totally accessible to subordinate laboratories. They are granted "self-management", "self-education" and "self-development". What is more, the seniors help and teach juniors. In this self-organization management mechanism, the core members of studios (students who are in charge of the studio) will exercise the organization and management functions, while all the other ordinary members exercise participation and the department exercise supervisory rights. The advantages under this brand-new laboratory management mechanism are following [4].

- The department and tutors are no longer the organizers and managers, while students get the autonomy to participate in innovation activities. In this way, more students will join in the innovation studios.

- Management mechanism of self-organization offers a new stable platform where students and teachers can communicate, thus building the bridge for comprehensive information between them.

- Management mechanism of self-organization established an unprecedented echelon of trainees where they are trained for management ability in innovation team. In self-organization, an echelon is formed unconsciously, in which students from high grade help students from low grade. An experienced student helps a freshman. Therefore, the efficiency of cultivating their innovation ability is improved and the innovation spirits can be handed down and developed.
- Management mechanism of self-organization integrates the educational resources of innovation. It not only provides a place for innovation, but greatly improves the rate of utilization of laboratories.

\section{CONCLUSION}

Aiming at how to stimulate the enthusiasm of undergraduates to innovate; how to improve cadets' innovative ability; how to effectively train cadets' innovative mind; how to instruct cadets to carry out innovative practice efficiently; how to teach cadets to manage their innovation team, etc. the paper focuses on the cultivation of students' innovative quality and thinking and creates a training method of students' innovation ability which include " 1 line, 7 procedures and 1 mechanism". The method has effectively solved the problem that the feasibility of current training program partly does not fit the top design of the education of talents. It has also created an environment for students in different levels to practice and innovate. The management mode of innovation team, including improving students' efficiency and helping them think out of the box, thus enhancing their ability to practice and their ability to innovate applying integrated knowledge

\section{REFERENCES}

[1] Yunkun Tan, Research on the Correlation of Innovation Competition and the Formation of Innovation Ability[D], 2010.12, Nanchang University.

[2] Arden Bement, Educate to Innovate-Factors That Influence Innovation-Based on Input from Innovators and Stakeholders[B], The National Academies Press USA, 2015.

[3] Xiaosong Guo, Implementing Excellent Tutorial System and Promoting Elite Education in Military Academies [J], Shanxi Jiaoyu·Gaojiao,2012 Vol 9: 86-88.

[4] Shengli Yan, Enlightenment of Self-organization Theory to Innovating Mechanism of the Military Academies Scientific Research management[J], Journal of the Chinese People's Armed Police Fo. 